\title{
Introduction to Tractate Avodah Zarah
}

The topic of the Tractate "Pagan Worship" is that of social interaction of Jews with pagan surroundings, in particular the possibility of keeping a kosher food supply in a non-Jewish (not necessarily pagan) world. Pagan practice as a matter of Jewish criminal law was dealt with in Tractate Sanhedrin.

The First Chapter starts with the general principle that three days before a public pagan feast commercial intercourse with pagans is forbidden. This refers to intrinsically pagan rites, not simply to non-Jewish festivities. For private festivities of pagan character, only the day itself is forbidden. The remainder of the Chapter is devoted to a description of public festivities in the later pre-Christian Roman Empire and the attenuated practical implementation of the general rule. The later part of the Chapter contains rules designed to preserve the Jewish character of Palestine.

The Second Chapter, the center piece of the Tractate, is divided into two parts. The first part is a complement of the First Chapter, detailing what to be careful about in dealing with Gentiles, not necessarily pagans. The second part starts the main topic of the Tractate, keeping a kosher food supply in a Gentile world. In this respect, a characteristic feature of rabbinic-pharisaic Judaism is the treatment of Gentile wine. Since it was generally accepted in the Greco-Roman world that wine drunk at any festive occasion was first dedicated to the gods by a libation (which mostly was done by gently wiggling the full cup), rabbinic interpretation considers any pagan wine as dedicated and therefore biblically forbidden for all usufruct for Jews. We do not know what the position of non-rabbinic sects was in this respect; the rule of the Damascus Document (CD xii 10) that it is forbidden to sell any wine (as well as grain and animals) to Gentiles lest they be used in idolatrous ways illustrates strict adherence to the rules of Chapter One.. On the other hand it is reported (in our Tractate, Chapter 5) that Samaritans did nor refrain from using Gentile wine; probably they forbade only wines actually used for pagan 
rites. Since the latter were either drunk or spilled by the worshippers, they could not be objects of trade. It is reported that the final split between Jews and Samaritans, attributed to R. Abbahu at Caesarea, was essentially caused by the difference in treatment of Gentile wine. Rabbinic Judaism has continued to ban Gentile wine even though the pagan background of the ban has disappeared. While the topic of Gentile wine is introduced in the Chapter, with extended remarks about the dangers of wine which was left uncovered and unattended, the main emphasis is on food rather than wine.

Chapter Three discusses the prohibition to use vessels decorated with pagan symbols of worship; arguments are given why public buildings decorated with such symbols may still be used. The general rule that natural phenomena, such as mountain tops, and buildings or trees connected to the ground cannot become forbidden by pagan use leads to a discussion of what is permitted and what is forbidden in buildings used for idolatry and sacred groves.

The Fourth Chapter again has two parts. The first part continues the Third Chapter in a description of Hermes worship and the general topic on how to remove the pagan aspect from objects of pagan worship. The second part deals with wine-presses; either Jewish owned with pagan workers or Gentile owned used to produce kosher wine. How to make a Gentile wine-press fit for the production of kosher wine is treated towards the end of Chapter Five.

The Fifth and last Chapter is almost completely dedicated to topics connected with wine; either the prohibition of Gentile wine or the problems of handling kosher wine in a Gentile environment. The last Halakhah deals with a different topic: How to prepare Gentiles' vessels for the preparation or use of kosher food (today called kashering.) The basis of the rules, both in their practical and their ritualistic aspects, is Num. 31:21-23. 